\title{
Beta-2 Glycoprotein 1 IgG Antibody Measurement
}

National Cancer Institute

\section{Source}

National Cancer Institute. Beta-2 Glycoprotein 1 Ig G Antibody Measurement. NCI

Thesaurus. Code C103358.

The determination of the amount of the Beta-2 glycoprotein 1 Ig G antibodies in a sample. 